\title{
PROPOSED MIGRATION CORRIDORS FOR LARGE MAMMALS IN THE SOUTH-EAST OF POLISH CARPATHIANS
}

\author{
Kajetan Perzanowski*a, Katarzyna Pędziwiatr ${ }^{\mathrm{b}}$, Paulina Konieczna ${ }^{\mathrm{b}}$ and Jan Śmiełowski ${ }^{\mathrm{b}}$
}

anstitute of Landscape Architecture, Catholic University of Lublin Konstantynów 1H, 20-708 Lublin, Poland; 'bnstitute for Agricultural and Forest Environment, Polish Academy of Sciences in Poznań Bukowska 19, 60-842 Poznań, Poland

*Corresponding author. Email: kajperz@wp.pl

Article history

Received: 11 September 2019; accepted 28 May 2020

\section{Keywords:}

Ecological corridors; the Carpathians; large mammals; habitat suitability; GIS

\begin{abstract}
The aim of the study was the delineation of migratory corridors migration for large mammals between the Ukrainian Carpathians and the western part of their range in Poland. Potential corridors for the wolf (Canis lupus), brown bear (Ursus arctos), lynx (Lynx lynx), wisent (Bison bonasus), red deer (Cervus elaphus), and wild boar (Sus scrofa) were identified within 534,818 ha with the ArcGIS Corridor Designer software. Corridors of regional importance (42,283 ha in total) and local connections between habitat patches $(13,154 \mathrm{ha})$ were delineated separately according to the least-cost path criterion. We identified 115 critical points where heavy traffic, or the proximity of settlements, could obstruct animal movements. A considerable number of such critical points indicate the urgency for ensuring the functionality of the remaining linkage. The permeability of barriers between habitat patches was determined by ground observations, confirming the presence of target species. The highest proportion of patches estimated by experts as optimal and suboptimal was for wild boar (91\%), while the lowest for lynx (52\%). The proportion of habitats avoided or useless due to anthropogenic barriers was $34 \%$ for lynx, $25 \%$ for wisents, and $19 \%$ for brown bears.
\end{abstract}

\section{INTRODUCTION}

The most fertile and therefore the most productive natural habitats of Europe became converted to agricultural land, commercial forests or built-up areas at least several centuries ago. Today, a majority of forests, wetlands or waste lands occupy marginal areas that were considered the least productive or unsuitable for economic development (Vera 2000; Vera and Buissink 2007).

Nevertheless, such areas now provide the last remaining refuges for our native wildlife. Due to a high degree of forest cover and low density of human settlements, mountain ranges like the Alps, Carpathians and Pyrenees are among the most important regions that may still provide functional migration routes for mammals on a continental scale (Corsi et al. 2002; Estreguil et al. 2014).

Due to the extreme variability of ecological niches for different species, it is virtually impossible to design a migration corridor that would be suitable for all the species populating a given study area (Gurrutxaga et al. 2011; Branton and Richardson 2011). Hence, we aimed at designing a potential corridor as a set of interconnected habitat patches fulfilling the needs of the species with the strictest requirements about habitat quality and dimensions. The selected habitat patches were suitable for species with a vastly different food base (both herbivores and predators). We thus limited our analysis to the brown bear (Ursus arctos), lynx (Lynx lynx), wolf
(Canis lupus), wisent (Bison bonasus), red deer (Cervus elaphus), and wild boar (Sus scrofa) - all well representing the requirements of their trophic categories, having various tolerance of antropopression and fairly common within the study area (Okarma and Tomek 2008; Meletti and Burton 2014; Górecki and Zemanek 2016).

Even relatively large habitat patches of satisfactory quality may only temporarily ensure the survival of wildlife populations. Their long-term persistence depends on conservation of genetic variability. Hence, it is necessary to provide possibilities for at least periodic exchanges of individuals among sub-populations, so that groups of animals, though isolated, can safely function as meta-populations. This often depends on the ability of, for example, solitary males to make long-distance movements (Jung 2017). That is why the maintenance of habitat patches that provide connections between the home ranges of a fragmented population is so important. Such conditions often occur within mountain ranges with habitats less altered by antropopression than surrounding areas are. The section of the Carpathians studied within the framework of this project fulfils these criteria due to its high percentage of forest cover and very low human population density (Corsi et al. 2002; Schnell et al. 2002).

The Carpathians, as the largest mountain chain in Central and Eastern Europe (with a length of approximately $1,500 \mathrm{~km}$ and covering an area of almost $210,000 \mathrm{~km}^{2}$ ), used to be a major natural corridor allowing for migra- 
tions of large mammals between the south-eastern part of the continent (Romania) and its central regions (northern Czech Republic). The great majority of this area remains covered by forests or semi-natural habitats such as alpine pastures and hay meadows. About $16 \%$ of the area of this mountain range is managed by various forms of environmental protection area, such as national parks, landscape parks, nature reserves and Natura 2000 sites, which represent important natural habitat patches and may provide effective ecological linkages. The Polish part of the Carpathians, which constitutes only about $10 \%$ of its whole area, links wildlife habitats occurring along the northern slopes of the range. This region is still inhabited by almost all the large mammals native to Europe, including predators such as wolf, lynx and brown bear and herbivores such as red deer, wild boar, wisent, roe deer (Capreolus capreolus), and chamois (Rupicapra rupicapra). Most of these species require access to vast home ranges representing high quality habitats (Webster et al. 2001).

However, this mountain range is becoming dissected by numerous communication routes with human settlements and recreational infrastructure encroaching on the mountain valleys. These barriers reduce the available area of optimal habitat patches and cause the demographic isolation of local animal populations (Forman et al. 2002; Skuban et al. 2017). Maintaining the continuity of natural habitats is crucial for effective nature conservation (Opdam 1997). Hence, in view of the size of the range and richness of this area's fauna, this aspect is very important in this part of the continent.

Ecological corridors as a formal form of nature conservation in Poland have so far only been mentioned in the Nature Conservation Act currently in force (passed in 2004 ) as areas ensuring migration of plants, animals or fungi, but lacking any regulations regarding their legal status (Kiczyńska and Weigle 2003). Even the Natura 2000 network, despite its name, consists of separate habitat patches, in most cases lacking any interconnections (Perzanowska and Grzegorczyk 2009). Nevertheless, the importance of ecological linkage is fully understood, and attempts to plan and establish more or less formal corridors on a local scale have been quite frequently undertaken (Perzanowska et al. 2005; Rogała and Marcela 2012).

Undoubtedly, the wider a migration corridor, the better the conditions it provides for ensuring animal movements. Nevertheless, in many cases due to irreversible transformation by agriculture or human infrastructure, it is already impossible to designate certain habitat strips for such a purpose. In addition, plans for establishing new protected zones are quite often not welcomed by local communities, who fear possible restrictions regarding their planned economic activities or the development of settlements. Strong local resistance to new protected areas may completely neutralize their effectiveness. For this reason, local communities should be consulted at a very early stage of such plans in order to achieve a final compromise acceptable to both sides (Jongman and Pungetti 2004; Bennett and Mulongoy 2006).

A concept for a network of ecological corridors in the Małopolska Province, covering the western section of the Carpathians on the Polish side was published in 2005 , and a project for the establishment of ecological corridors in the Ukrainian Carpathians between the Romanian and Polish borders was completed in 2010 (Perzanowska et al. 2005; Bashta et al. 2010). That, however, left a considerable gap in securing ecological connectivity within the Polish section of the Carpathians in the south-eastern corner of the country.

The aim of this project was to identify potential pathways for large mammals, connecting already delineated ecological corridors in Ukraine and the Małopolska Province of Poland, and to indicate their points of connection to large forest complexes situated to the north within the Carpathian foothills. This would fill the gap in the planned maintenance of ecological connectivity along one of the largest European mountain chains and contribute to the survival of local populations of endangered large mammals.

\section{Study area, materials and methods}

During 2014-2015, we analysed 534,818 ha in the south-eastern part of Poland (the Podkarpacie Province), 476,045 ha of which are administered by the State Forest Service. Within this area there are two national parks, six landscape parks, four Natura 2000 Special Protection Areas for birds, and eleven Special Areas of Conservation established under the Habitat Directive, as well as two promotional forest complexes, two areas of protected landscape, and over 40 nature reserves (Górecki and Zemanek 2016; Zieliński 2010).

The boundaries of the project area were determined by the Regional Directorate of State Forests at Krosno, Bieszczadzki and Magurski national parks (NPs) and the ProCarpathia Foundation which was the project coordinator. The project area included two largest protected areas of the region (both NPs) and 11 forests districts: Baligród, Bircza, Cisna, Dukla, Komańcza, Lesko, Lutowiska, Rymanów, Stuposiany, Ustrzyki Dolne, and Kołaczyce, which were indicated by the Forest Service as important mainstays for large mammals (Figure 1).

Land cover data were provided by the Forest Service in the form of current numerical raster maps used for planning forest management, consisting of thematic layers representing all considered categories of vegetation, 


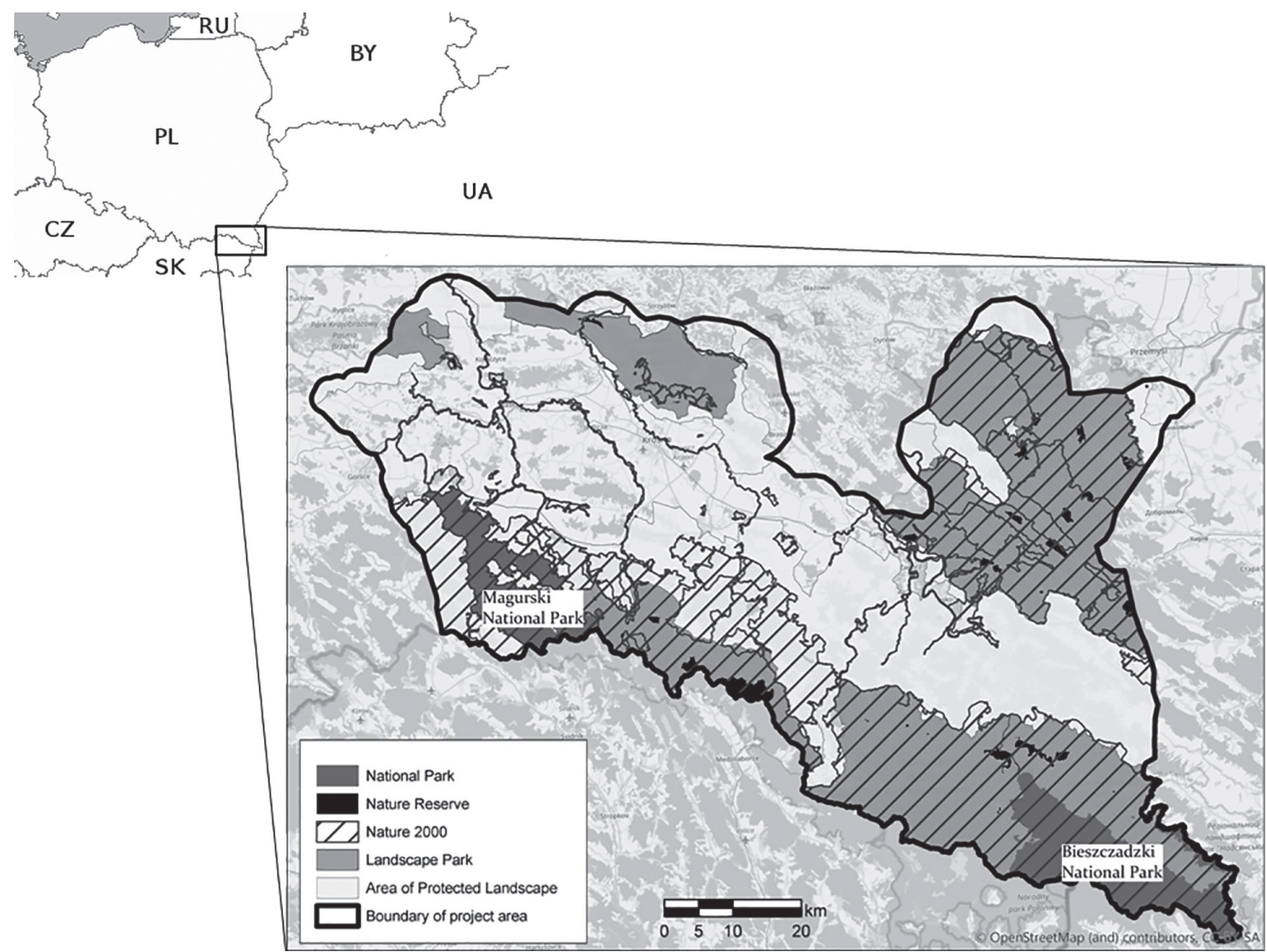

Figure 1. The area of the project with marked nature reserves, national parks, Natura 2000 sites, landscape parks, and areas of protected landscape.

features of terrain, and infrastructure (Table 1). Maps of development plans valid for years 2014-2015 were provided by local administrations.

Forests cover $56.31 \%$ (369,115 ha) of the study area, while built-up areas and infrastructure, including communication routes, constitute only $4.39 \%$ (28,830 ha). Agricultural land, including meadows and recently abandoned fields, amounts to $38.31 \%$ (251,060 ha). Surface waters, wetlands and forest openings account for the remaining area. The total length of public roads within the study area amounts to $5,057 \mathrm{~km}$. According to the data obtained from the Forest Service and both national parks participating in the project, during implementation of the project, the study area was inhabited then by over 5,500 red deer, almost 3,000 wild boar, about 400 wolves, 300 European bison, almost 200 brown bears, and over 190 lynx (Perzanowski et al. 2015). The project consisted of several phases. The first one included identification and categorisation of habitat patches and links as potential migration corridors for the wolf, brown bear, lynx, wisent, red deer, and wild boar. For every animal species that was considered, the spatial distribution of suitable environmental conditions was determined on the basis of the following parameters (all options made available by the software ArcGIS Corridor Designer, according to Majka et al. (2007)): (1) land cover - 14 classes (listed in Table 1), (2) distance from public roads, (3) distance from built-up areas, (4) ratio of forest cover to open areas within a $250 \mathrm{~m}$ radius, (5) elevation above sea level, (6) relative elevation $v s$. surrounding pixels in a $200 \mathrm{~m}$ radius, and presented as thematic layers of the GIS model. The software rates habitat suitability according to raster-based layers representing various environmental factors. A combination of such data and a habitat suitability threshold that ranks habitat quality makes it possible to identify optimal connections between habitat blocks suitable for supporting a viable population of a given species or at least habitats sufficient for the species to breed (Majka et al. 2007).

Habitat suitability was estimated based on literature data and experts' knowledge regarding relationships between the pattern of habitat use by particular animal species and values of selected habitat parameters. Each parameter characterising habitat conditions was reclassified in order to attribute to each pixel in the various thematic layers a value representing the intensity of habitat use by the animal species covered by the study. All analysed environmental factor layers were converted to raster data, and the index of habitat suitability was calculated for every pixel of the habitat map $(10 \times 10 \mathrm{~m})$. This methodology was based on papers by Clevenger et al. (2002) and Bashta et al. (2010) (Table 1).

In the next step, the size of a home range typical of each species was estimated based on areas fulfilling the criteria of population patches, breeding patches, 
and those patches of adequate habitat quality that were too small for a breeding patch. Subsequently, using an algorithm analysing all possible connections between habitat patches suitable for supporting a viable population or for breeding, the shortest possible links were found by following the method of the least-cost path, i.e. pursuing such course of movements where the level of environmental resistance is the lowest (Majka 2007).The permeability of corridors potentially suitable for animal passage was verified by means of detection of animal crossings over local roads, which was done by forest and park rangers on the basis of direct observations, camera traps, and tracking. Estimate of the width of each link and its usefulness was undertaken whilst considering its surroundings, including vegetation cover, terrain, proximity of settlements, and volume of traffic.

In the last step, the extent of identifiable habitat patches and migration corridors was compared with local development plans to exclude the areas for which their suitability for wildlife will be inevitably lost in the near future.

Values of environmental parameters were in turn assigned as weights corresponding to the intensity with which a given parameter influenced the pattern of habitat use by particular animal species. Due to close similarity among environmental conditions and composition of local fauna, we based our estimate of these weights on the values adopted in a study of ecological corridors in the Ukrainian Carpathians (Bashta et al. 2010) (Table 2).

The value of each parameter in the habitat suitability model was calculated by means of the ArcGIS Corridor Designer software for each particular raster of the map. Spatial distribution of the values for each parameter we considered was displayed as a separate thematic layer of the map. The complete habitat suitability model was obtained with algorithms enabling calculation of the habitat suitability index (HSI) for each raster of the habitat as a resulting combination of all the thematic layers (Majka et al. 2007).

On the basis of this habitat suitability model, after consideration of thresholds for minimal suitability of habitat patches (assumed as at least 50\%) and the size of home ranges typical of the species covered by the project, three types of habitats useful for wildlife were identified: population patches, breeding patches, and $<$ breeding patches. The fourth category includes habitats that are

Table 1. Ranks for the classes of ground cover assumed for particular animal species on the basis of experts' opinion (Forest Service and national park staff) considered in the study on migration corridors in the Polish Carpathians $(1=$ the highest quality, $10=$ the lowest quality).

\begin{tabular}{|l|c|c|c|c|c|c|}
\hline \multirow{2}{*}{\multicolumn{1}{c|}{ Classes of ground cover }} & \multicolumn{7}{c|}{ Species } \\
\cline { 2 - 7 } & Brown bear & Wolf & Lynx & Red deer & Wild boar & Wisent \\
\hline Coniferous forest & 1 & 2 & 1 & 2 & 2 & 2 \\
\hline Deciduous forest & 1 & 2 & 1 & 1 & 1 & 1 \\
\hline Mixed forest & 1 & 1 & 1 & 1 & 1 & 1 \\
\hline Arable land & 8 & 7 & 9 & 7 & 4 & 6 \\
\hline Meadows and waste land & 6 & 4 & 6 & 4 & 5 & 2 \\
\hline Water bodies $>1$ ha & 10 & 9 & 10 & 10 & 10 & 10 \\
\hline Watercourses & 8 & 5 & 8 & 5 & 3 & 8 \\
\hline Continuous settlements & 10 & 10 & 10 & 10 & 10 & 10 \\
\hline Scattered buildings & 9 & 9 & 10 & 9 & 8 & 9 \\
\hline Meadows $>1200$ m a.s.l. & 5 & 4 & 7 & 5 & 6 & 4 \\
\hline Wetlands & 8 & 5 & 8 & 5 & 3 & 8 \\
\hline Strongly altered by human pressure & 9 & 9 & 10 & 9 & 8 & 10 \\
\hline Permanent cropland & 7 & 7 & 8 & 6 & 3 & 4 \\
\hline Railways & 4 & 4 & 5 & 4 & 4 & 5 \\
\hline
\end{tabular}

Table 2. Weights of particular environmental factors applied in habitat quality assessment for animal species considered in the study on migration corridors in the Polish Carpathians (after Bashta et al. (2010)).

\begin{tabular}{|c|c|c|c|c|c|c|}
\hline \multirow{2}{*}{ Environmental factor } & \multicolumn{6}{|c|}{ Species } \\
\hline & Brown bear & Wolf & Lynx & Red deer & Wild boar & Wisent \\
\hline Ground cover & 1 & 1 & 1.5 & 1 & 2 & 2 \\
\hline Elevation & 1 & 1 & 1 & 1 & 1 & 1 \\
\hline Relative elevation in the radius of $250 \mathrm{~m}$ & 1 & 1 & 1 & 1 & 1 & 1 \\
\hline Forest/open area ratio in the radius of $250 \mathrm{~m}$ & 1 & 1 & 1.5 & 1 & 1 & 1.5 \\
\hline Proximity of settlements & 2 & 3 & 2 & 2 & 1 & 1.5 \\
\hline Distance from roads & 1.5 & 1 & 2 & 1.5 & 1 & 1.5 \\
\hline
\end{tabular}


avoided or useless (e.g. roads, settlements, lakes, etc.). The software counts population patches as the areas that allow the functioning of a viable population of a given species for at least 10 years (minimal size 5,000 ha). In turn, breeding patches are the areas allowing a single case of breeding of a given species (minimal size 1,000 ha), while $<$ breeding patches represent areas that are of sufficient habitat quality but too small to fulfil the requirements for the survival or breeding of particular species selected for this study (Majka et al. 2007).

The least-cost path (LCP) links between population patches, i.e. the shortest distance between habitat patches of the highest possible quality with the lowest environmental resistance (Adriaensen et al. 2003), were identified at four corners of the project area (south-east, south-west, north-east, and north-west: the Bieszczadzki NP, the Magurski NP, the Bircza Promotional Forest Complex, and the Czarnorzecko-Strzyżowski Landscape Park). Based on the size of aforementioned areas and the data for population numbers of species in this study we assumed that all these protected areas fulfilled the criteria of population patches. The ArcGis Corridor Designer software returns a raster, in which the sum of cost distances (accumulative costs) between the cell and two nearest population patches (sources) is calculated for each cell location. Therefore, the sum of two raster costs identifies for each cell location the least-cost path from one source to another that passes through the cell location. As a result, the raster representing a range of accumulative costs between two pairs of neighbouring patches is obtained. All cells with values below a maximum adopted threshold represent the area of a least-cost corridor (Majka et al. 2007).

Based on the experience and field observations of the staff of the Forest Service and rangers of two national parks, connections between population patches that were most important for the functioning of local animal populations were identified within the study area. The highest elevations within this area do not exceed 1,346 $\mathrm{m}$ above sea level (Tarnica, the highest peak in Bieszczady), and mountain ridges are either forested or covered with alpine meadows, posing no serious obstacle for animal movements. It was, therefore, assumed that the main public roads, built-up areas and a large dam reservoir (Solina Lake) were the main barriers to migration.

Local connections identified by the model were verified by means of records of animal crossings obtained through observations, snow tracking, camera traps, records of traffic collisions, etc. collected by the staff of the Forest Service and two national parks between 2012-2015. Such evidence was collected for all main public roads running between neighbouring habitat patches within the project area and being potential barriers to animal movements.
Among 7,715 of such records, 5,984 were of red deer, 769 of wolf, 670 of wild boar, 169 of brown bear, 70 of wisent, and 53 of lynx. On the basis of such data, it was possible to indicate the location and width of local connections between neighbouring populations and breeding habitat patches important for the functioning of populations of species considered in this study (Figure 2). The actual width of local connections between neighbouring patches was assessed individually through consultations with local forest and park rangers having first-hand knowledge of conditions existing in situ (e.g. proximity of buildings, exceptionally rough or inaccessible terrain, existing fencing, etc.).

Various options were tested for the width of migration corridors as provided by the ArcGIS Corridor Designer software (available as "slices" of between $0.1 \%$ and $10 \%$ of the modelled area) (Majka et al. 2007). However, due to objections raised by the Forest Service regarding introduction of a new category of protected areas, which could result in restrictions regarding logging patterns and schedule, project coordinators finally accepted the minimum possible "slices", i.e. $0.1 \%$, as sufficient, thus ensuring connectivity between habitat patches and linking opposite sides of the project area (Figure 3).

\section{RESULTS}

The proportions of distinctive categories of habitat patch differed considerably among particular animal species. The highest proportion of the total available optimal and suboptimal patches was for wild boar (91\%), whereas the lowest was for lynx (51\%). For other species (wolf, brown bear, wisent, and red deer) this proportion ranged between $61-73 \%$. For species such as lynx, wisent, red deer, and brown bear, a large part of the area, i.e. the sum of strongly avoided and absolutely non-useful habitats $(34,25,21$, and $19 \%$, respectively), remained useless due to anthropogenic barriers and transformed habitats, although such unfavourable conditions occurred only in about 3 and $4 \%$ of available area for wild boar and wolf, respectively (Table 3, Figure 4).

In order to ensure the permeability (i.e. functionality) of the network of delineated potential migration corridors, we identified 115 critical points where important connections between habitat patches suitable for supporting animal movements across roads were under threat due to their narrowness, presence of heavy traffic or close proximity of human settlements. Such points were identified separately for every forestry area by local rangers, taking into account the frequency of animal crossings, the width of accessible suitable habitat (proper vegetation cover), frequency of traffic, and local plans for the extension of infrastructure (Figure 5). 


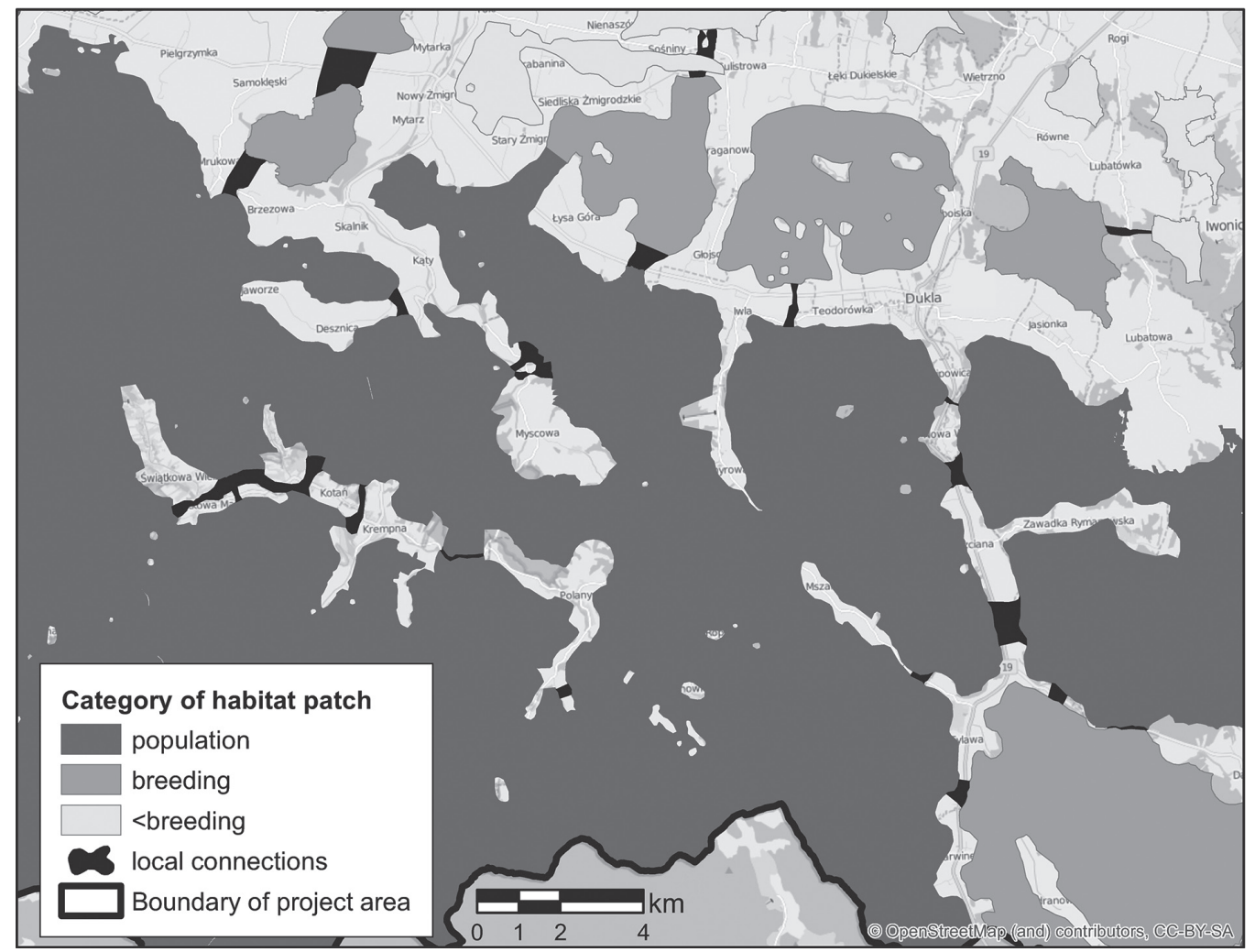

Figure 2. An exemplary fragment of the habitat map showing connections between neighboring population and breeding habitat patches, indicated by the staff of Forest Service and national parks as important for maintenance of viable populations of large mammals in the area.

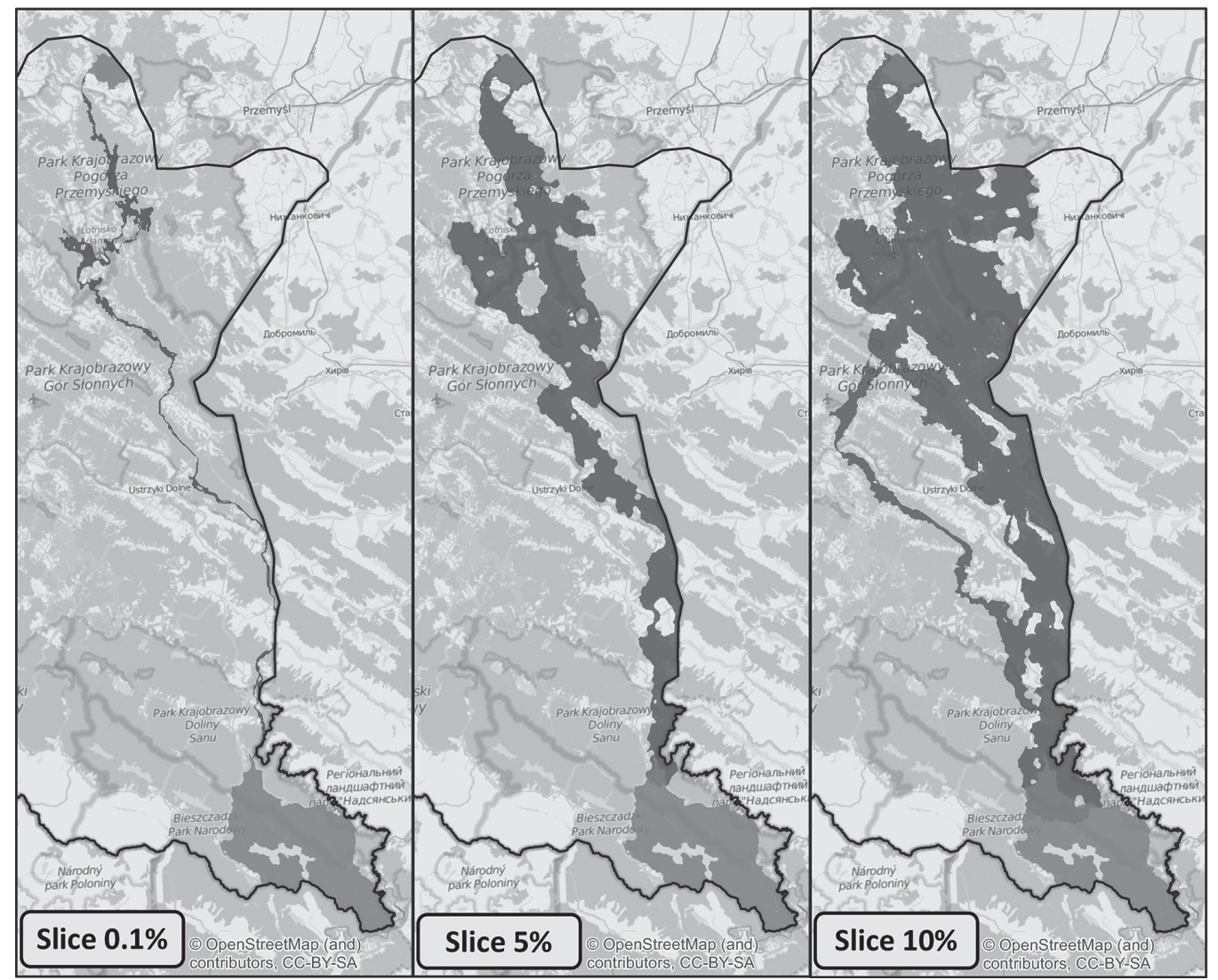

Figure 3. A comparison of the width of migration corridors (assumed "slices" of 0.1, 5.0 and 10\%) between Bieszczadzki National Park in the south, and Landscape Park of Przemyskie Foothills. 
Table 3. The percentage of the area of different quality (4 categories) habitat patches (after Majka et al. (2007)) falling to six species of large mammals considered in the study on migration corridors in the Polish Carpathians.

\begin{tabular}{|l|c|c|c|c|}
\hline $\begin{array}{c}\text { Species/ } \\
\text { /Habitat }\end{array}$ & $\begin{array}{c}\text { Optimal } \\
\text { Population patches }\end{array}$ & $\begin{array}{c}\text { Suboptimal } \\
\text { Breeding patches }\end{array}$ & $\begin{array}{c}\text { Occasionally used } \\
<\text { Breeding patches }\end{array}$ & $\begin{array}{c}\text { Strongly avoided or } \\
\text { absolutely not useful }\end{array}$ \\
\hline Lynx & 35 & 16 & 15 & 34 \\
\hline Wolf & 51 & 22 & 23 & 4 \\
\hline Brown bear & 40 & 21 & 20 & 19 \\
\hline Wisent & 36 & 29 & 10 & 25 \\
\hline Red deer & 46 & 24 & 9 & 3 \\
\hline Wild boar & 56 & 35 & 6 & 21 \\
\hline
\end{tabular}
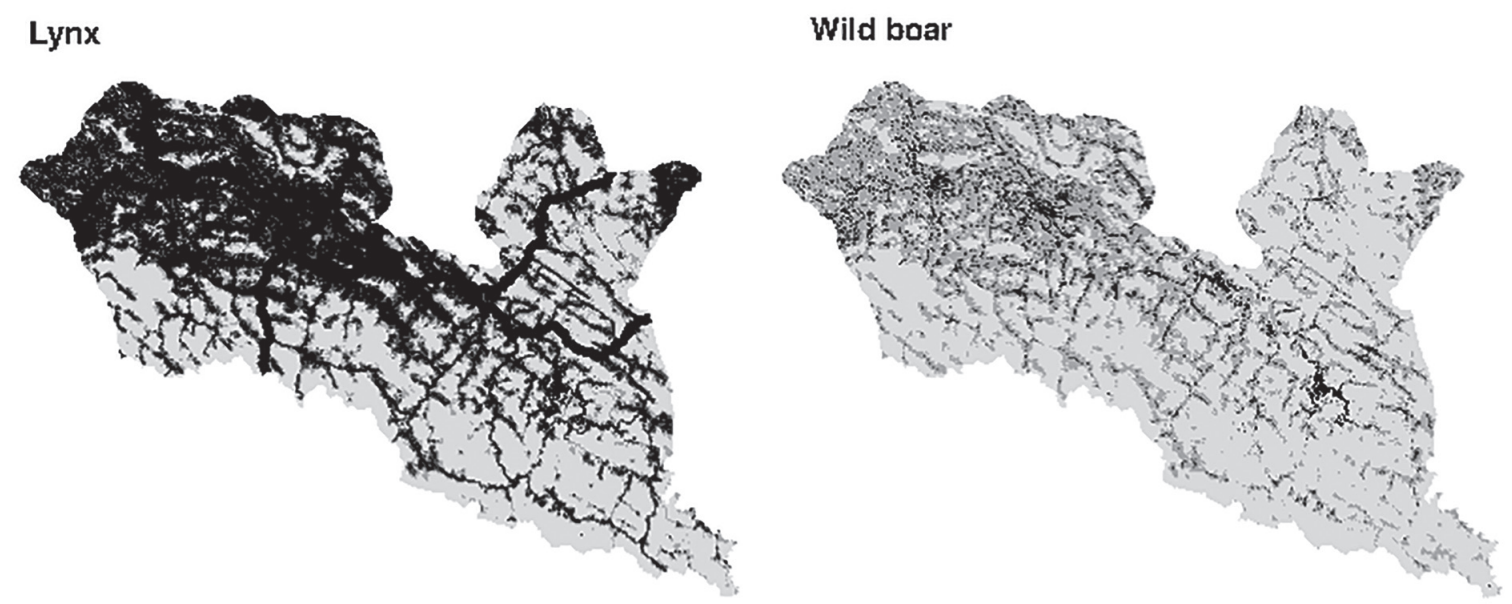

\section{Habitat categories}
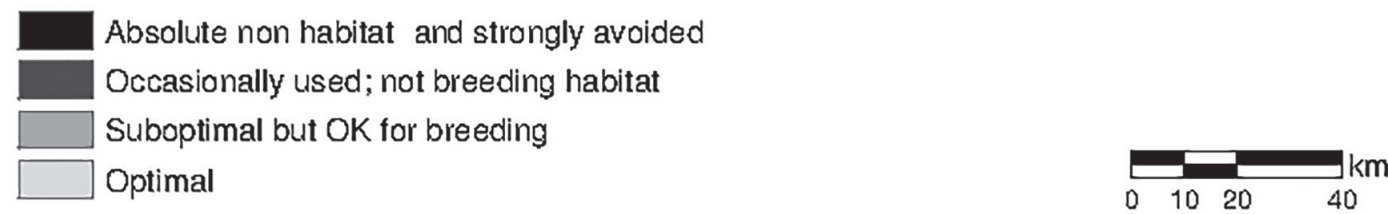

Figure 4. A comparison of distribution of habitat patches belonging to four categories of habitat quality (after Majka et al. 2007), determined for wild boar and lynx within the project area.

\section{DISCUSSION}

We have identified a network of potential migration corridors along the main ridge of the Carpathians to connect two national parks, as well as some alternative routes situated several kilometres north. We also found a good connection providing possibilities for animal movement towards the north from the Bieszczady National Park, an important factor for maintaining a connection between the forests in the central section of the Carpathians and the main forest complexes of the Carpathian foothills (the Bircza Promotional Forest Complex). We also mapped the course of the most important connections from the Magurski National Park and an important and sizeable protected area situated to the north (the Czarnorzecko-Strzyżowski Landscape Park). The total area which, as potential migration corridors, should optimally be protected against changes in land cover and further fragmentation amounts to 53,399 ha, of which
42,283 ha constitute regional corridors, while 13,154 ha provide local connections (with these two types of connection overlapping in some cases) (Figure 6).

The total area of corridors that fulfilled habitat requirements for all six species we analysed amounted to over $39 \%$ of the entire study area. There was no chance of such a proposal being approved for implementation by all interested parties (especially the local administration and the Forest Service). Finally, only the corridor based on the requirements of the red deer was accepted.

It is especially important to properly identify any critical point that might endanger the continuity of habitats suitable for supporting animal movements, either due to further expansion of built-up areas or increase in traffic volume. The narrowest sections of potential corridors may become a dead end for animal migration in such situations (Gurrutxaga et al. 2011). Therefore, apart from estimating habitat quality and the total size of habitat patches, it is also necessary to assess potential obstacles 


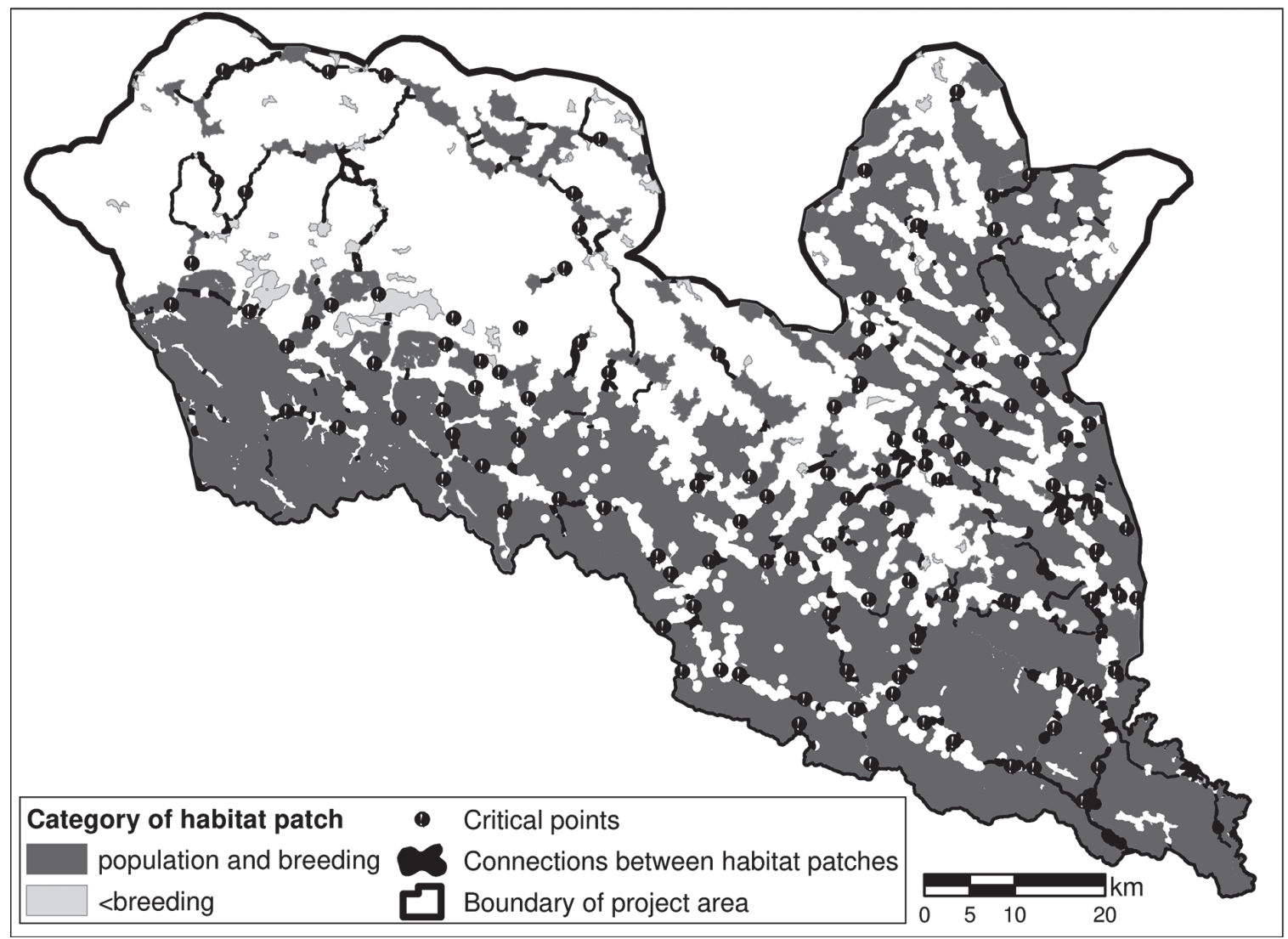

Figure 5. Identified local connections between habitat patches and points critical for the maintenance of ecological connectivity within the project area.

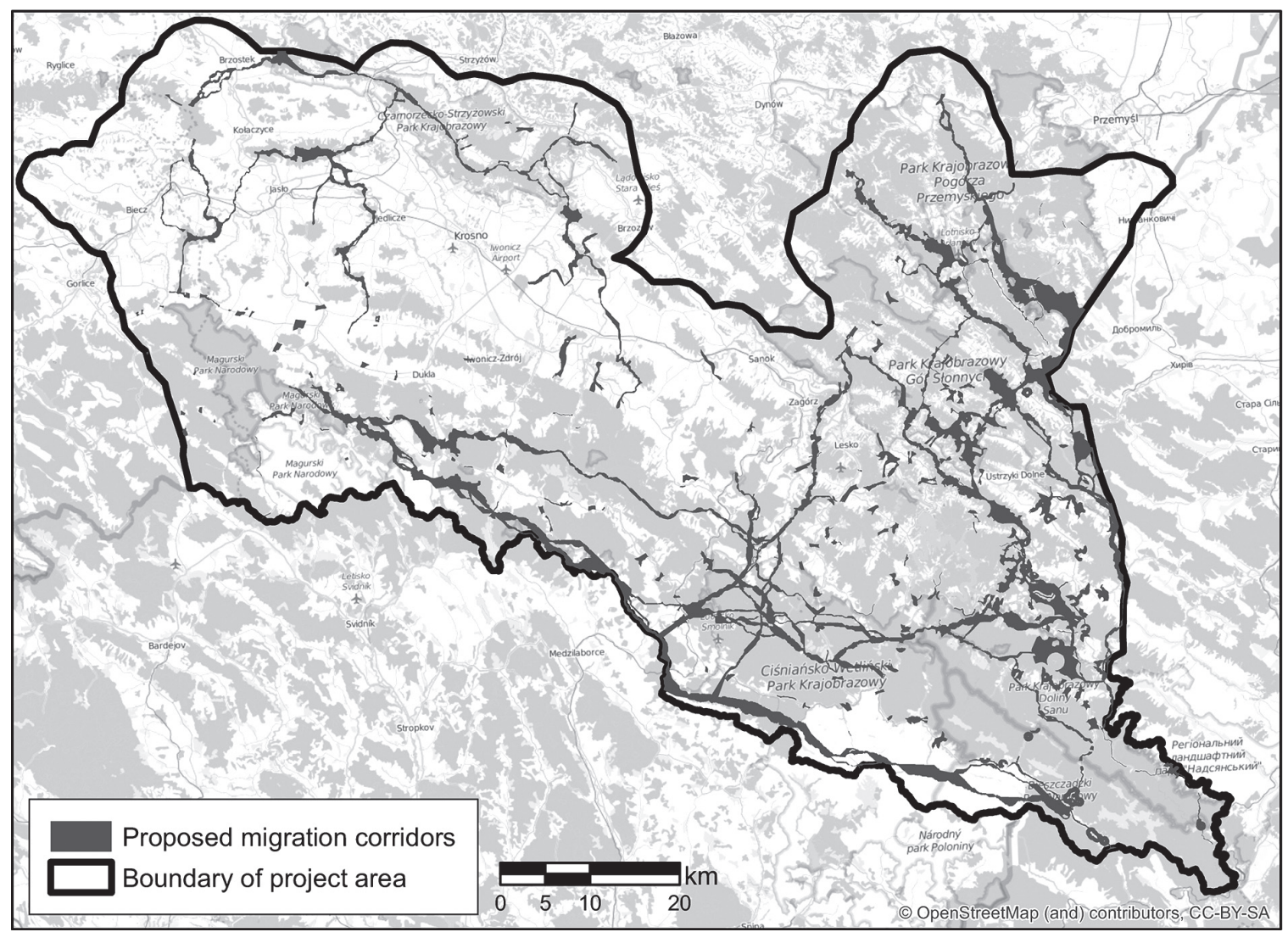

Figure 6. The course of proposed migration corridors within the studied area. 
to animal movements at their peripheral points where the distance to the next nearest suitable habitat patch is the shortest. Otherwise, even a well-planned and fairly long migration corridor may become ineffective if migration to more distant habitat patches becomes totally disrupted. The considerable number of such critical points identified in this project reflects an important aspect of habitat fragmentation, i.e. the loss of connectivity that creates urgency in ensuring the functionality of any remaining linkage (Perzanowski et al. 2015) (Figure 5).

It is quite frequently found that those suitable habitat patches which persist have already become separated due to human infrastructure, creating barriers to wildlife migration that are difficult to overcome even impassable, like the road No S19 within our study area that leads to the Polish-Slovak border. There exist, however, certain possibilities for mitigating such difficulties, including reforestation of waste land or strips of abandoned land at critical points along potential migration corridors or construction of overpasses. However, both these solutions are costly and require several time-consuming bureaucratic procedures (García-Feced et al. 2011; Lewandowski et al. 2015). Nevertheless, in some cases such actions may be indispensable to prevent permanent isolation of local wildlife populations. Such suggestions were formulated in the the final project report (Perzanowski et al. 2015).

Traditional concepts of nature conservation based on the protection of isolated sites such as national parks or nature reserves are insufficient to ensure that genetic variability in large mammal populations is maintained. Effective protection can only be guaranteed by means of a spatial network consisting of sizeable protected areas connected by functional migration corridors. The proposed ecological corridors for south-eastern Poland may provide linkage between Natura 2000 sites in southern Poland, northern Slovakia and the Czech Republic with the south-eastern sites of this network in Romania (Perzanowski 2012). In addition, the critical points identified between neighbouring habitat patches could be included in spatial planning at a local community or forest district level as zones to be protected against infrastructure encroachment and deforestation.

\section{CONCLUSIONS}

The network of potential migration corridors as proposed in this study may be helpful in preparing local plans for land development that are aimed towards maintaining natural values of the area. This should include ensuring possibilities for migration of large mammals, which is important not only along one of the largest European mountain ranges - the Carpathians, but also for maintaining the existing connections between the forest habitats of this range and its foothills. Due to the present policy of the Polish Forest Service, fully respecting all biological functions of the forest, as opposed to treating it like in the past as merely a source of timber, the future continuity of forest complexes seems assured. However, there is an urgent need to maintain or improve connectivity between forest habitat patches that may be endangered by further development of road infrastructure and encroachment of built-up areas. The most threatened are the remaining narrow connections (critical points) between neighbouring patches suitable for wildlife, which are easily destroyed through activities like deforestation or introduction of new infrastructure. Therefore, in our opinion, proper identification of critical points for functional local connections between habitat patches, and the mapping of their spatial parameters, are the most important issues for effective protection of migration routes for the region's fauna in order to prevent isolation of local subpopulations of large mammals.

\section{ACKNOWLEDGEMENTS}

This study was based on the results of the project KIK 53 (Swiss Contribution) "Protection of refuges for the fauna of Carpathian primeval forest - migration corridors", coordinated by Pro Carpathia Association for the Development and Promotion of Podkarpacie. The authors also wish to thank Prof. Andrzej Kędziora for his critical comments, and anonymous reviewers for their suggestions contributing to the quality of the paper.

\section{CONFLICT OF INTEREST}

The authors declare that they have no conflicts of interest.

\section{ETHICAL APPROVAL}

This study did not involve any experiments with animals and humans.

\section{REFERENCES}

Adriaensen, F., J. P. Chardon, G. De Blust, E. Swinnen, S. Villalba, H. Gulinck, and E. Matthysen. 2003. The application of 'least-cost' modelling as a functional landscape model. Landscape and Urban Planning 64: 233-247.

Bashta, A., I. Kruhlov, V. Korzhyk, S. Tatuh, M. Bilokon, M. Shkitak, I. Movchan, S. Catanoiu, K. Perzanowski, L. Davids, and P. Bakker. 2010. Creation of ecological corridors in Ukraine. State Agency for Protected 
Areas of the Ministry of Environmental Protection of Ukraine, Altenburg \& Wymenga Ecological Consultants, Interecocentre Kyiv.

Bennett, G., and K. J. Mulongoy. 2006. Review of Experience with Ecological Networks, Corridors and Buffer Zones. Montreal: Secretariat of the Convention on Biological Diversity, Technical Series No. 23.

Branton, M., and J. S. Richardson. 2011. Assessing the value of the umbrella-species concept for conservation planning with meta-analysis. Conservation Biology 25: 9-20.

Clevenger, A. P., J. Wierzchowski, B. Chruszcz, and K. Gunson. 2002. GIS-generated, expert-based models for identifying wildlife habitat linkages and planning mitigation passages. Conservation Biology 16: 503-514.

Corsi, F., I. Sinibaldi, and L. Boitani. 2002. Ecological corridors and species: Large carnivores in the Alpine Region. No 127. Strasbourg: Council of Europe, Nature and Environment.

Estreguil, C., G. Caudullo, and D. de Rigo. 2014. Connectivity of Natura 2000 forest sites in Europe. Computational Engineering, Finance, and Science (cs.CE); Populations and Evolution (q-bio.PE), F1000 Posters 5: 485.

Forman, R. T. T., J. Bissonette, A. Clevenger, C. Cutshall, V. Dale, L. Fahrig, C. Goldman, K. Heanue, J. Jones, D. Sperling, F. Swanson, T. Turrentine, and T. Winter. 2002. Road ecology: Science and solutions. Washington DC: Island Press.

García-Feced, C., S. Saura, and R. Elena-Rosselló. 2011. Improving landscape connectivity in forest districts: a two-stage process for prioritizing agricultural patches for reforestation. Forest Ecology Management 261: 154-161.

Górecki, A., and B. Zemanek (eds.) 2016. Bieszczadzki Park Narodowy - 40 lat ochrony. [Bieszczadzki National Park-40 years of protection]. Poland: BdPN, Ustrzyki Dolne (In Polish with English summary).

Gurrutxaga, M., L. Rubio, and S. Saura. 2011. Key connectors in protected area networks and the impact of highways: a transnational case study from the Cantabrian Range to the Western Alps. Landscape and Urban Planning 101: 310-320.

Jongman, R. H. G., and G. Pungetti (eds.) 2004. Ecological networks and greenways: concept, design, implementation. Cambridge: Cambridge University Press.

Jung, T. S. 2017. Extralimital movements of reintroduced bison (Bison bison): implications for range expansion and human-wildlife conflicts. European Journal of Wildlife Research 63: 35.

Kiczyńska, A., and A. Weigle. 2003. Jak zapewnić spójność sieci Natura 2000, czyli o korytarzach ekologicznych. In Ekologiczna sieć Natura 2000, problem czy szansa, 169-182, edited by Makomaska-Juchiewicz, M., and Tworek, S.). Poland: IOP PAN, Kraków (In Polish).

Lewandowski, W., R. Kowalczyk, S. Bienias, A. Bernatek,
M. Jakiel, M. Górny, P. Kupczyk-Kuriata, A. Bienias, L. Duduś, A. Gorczewski, and T. Podgórski. 2015. Program ochrony pólnocnego korytarza ekologicznego. Warszawa, Poland: WWF Polska (In Polish).

Majka, D., J. Jenness, and P. Beier. 2007. CorridorDesigner: ArcGIS tools for designing and evaluating corridors. http://corridordesign.org. Accessed 15 February 2019

Meletti, M., and J. Burton (eds.) 2014. Ecology, evolution and behaviour of wild cattle. Cambridge, UK: Cambridge University Press.

Okarma, H., and A. Tomek. 2008. Łowiectwo. Kraków, Poland: Wyd. Edukacyjno-Naukowe $\mathrm{H}_{2} \mathrm{O}$ (In Polish).

Opdam, P. F. M. 1997. How to choose the right solution for the right fragmentation problem? In Habitat fragmentation and infrastructure, 55-60, edited by Canters, K. Delft. The Netherlands: Ministry of Transportation, Public Works and Water Management.

Perzanowska, J., and M. Grzegorczyk. 2009. Obszary Natura 2000 w Małopolsce. Kraków, Poland: Instytut Ochrony Przyrody PAN (In Polish).

Perzanowska, J., M. Makomaska-Juchiewicz, G. Cierlik, W. Król, , S. Tworek, , B. Kotońska, and H. Okarma. 2005. Korytarze ekologiczne w Małopolsce. Kraków, Poland: Instytut Nauk o Środowisku i Instytut Ochrony Przyrody PAN (In Polish).

Perzanowski, K. 2012. Korytarze ekologiczne dla dużych ssaków w Karpatach. [Ecological corridors for large mammals in the Carpathians]. Roczniki Bieszczadzkie 20, 123-133 (In Polish with English summary).

Perzanowski, K., K. Pędziwiatr, P. Konieczna, J. Śmiełowski, and A. Kędziora. 2015. Opracowanie mapy korytarzy migracyjnych wraz z komentarzem $w$ ramach projektu KIK 53: „Ochrona ostoi karpackiej fauny puszczańskiej - korytarze migracyjne”. Poznań, Poland: Instytut Środowiska Leśnego i Rolnego, Polskiej Akademii Nauk (In Polish).

Rogała, D., and A. Marcela. 2012. Obszary Natura 2000 na Podkarpaciu. Poland: RDOŚ w Rzeszowie (In Polish).

Schnell, J. K., G. M. Harris, S. L. Pimm, and G. J. Russell. 2013. Estimating extinction risk with metapopulation models of large-scale fragmentation. Conservation Biology 27: 520-30.

Skuban, M., S. Find'o, M. Kajba, M. Koreň, J. Chamers, and V. Antal. 2017. Effects of roads on brown bear movements and mortality in Slovakia. European Journal of Wildlife Research 63: 82.

Vera, F. W. M. 2000. Grazing ecology and forest history. Wallingford: Cabi Publishing.

Vera, F. W. M., and F. Buissink. 2007. Wilderness in Europe. Baarn, The Netherlands: Tirion Natuur.

Webster, R., S. Holt, and C. Avis (eds.). 2001. The status of the Carpathians. Vienna, Austria: WWF-The Carpathian Ecoregion Initiative Report.

Zieliński, K. (ed.). 2010. Leksykon podkarpackiej przyrody. Rzeszów, Poland: ProCarpathia (In Polish). 